\title{
ANALISIS FAKTOR-FAKTOR DOMINAN YANG BERPENGARUH TERHADAP PEMILIHAN PERGURUANTINGGI DENGAN MENGGUNAKAN METODE ANALYTICAL HIERARCHY PROCESS (AHP) (STUDI KASUS SMA/SMK DI PROVINSI BALI)
}

\author{
Dewa Ayu Putu Alit Candra Dewi, Nyoman Dantes, Gede Rasben Dantes \\ Program Studi Penelitian dan Evaluasi Pendidikan, Program Pascasarjana \\ Universitas Pendidikan Ganesha \\ Singaraja, Indonesia
}

e-mail: \{candra.dewi1;nyoman.dantes; rasben.dantes \}@pasca.undiksha.ac.id

\begin{abstract}
Abstrak
Tujuan dari penelitian ini adalah untuk mengetahui faktor-faktor dominan yang berpengaruh dalam memilih perguruan tinggi bagi siswa/siswi SMA/SMK di provinsi Bali. Penelitian ini merupakan penelitian evaluasi kebijakan melalui rancangan penelitian eksploratoris. Metode analisis data dalam penelitian ini adalah deskripsi kuantitatif. Teknik pengambilan sampel yang digunakan adalah multistage random sampling. Sampel dalam penelitian ini adalah siswa kelas XII SMA/SMK di provinsi Bali yang banyaknya 2.543 siswa dari jumlah populasi 128 sekolah. Teknik analisis data yang digunakan yaitu AHP (Analytical Hierarchy Process). Dari 11 faktor yang diteliti, diperoleh bahwa 3 ranking teratas terkait faktor yang paling dominan dalam menentukan perguruan tinggi di provinsi Bali yaitu faktor motivasi untuk bekerja dengan nilai eigenvector $=0,3617$, faktor biaya pendidikan dengan nilai eigenvector $=$ 0,2030 , dan faktor produk dengan nilai eigenvector $=0,0884$. Walaupun jika dilakukan analisis terpisah antara kelompok SMA dan SMK ditemukan kesamaan 3 faktor teratas yang berpengaruh terhadap pemilihan perguruan tinggi yaitu faktor motivasi untuk bekerja, faktor biaya pendidikan dan faktor produk. Hasil penelitian menunjukkan bahwa tidak ada perbedaan antara kelompok SMA dan SMK terhadap faktor yang paling dominan dalam pemilihan perguruan tinggi, baik kelompok SMA maupun SMK memilih faktor motivasi untuk bekerja merupakan faktor yang paling dominan. Hal ini menunjukkan bahwa baik siswa/siswi SMA maupun SMK memprioritaskan untuk bekerja setelah lulus dari perguruan tinggi. Oleh karena itu, ke depan perguruan tinggi seharusnya lebih mempromosikan profil lulusannya dibandingkan dengan profil perguruan tingginya dan lebih mengutamakan dalam peningkatan kualitas proses pembelajaran sehingga dapat menghasilkan lulusan yang berkualitas dan mampu bersaing di dunia kerja.
\end{abstract}

Kata kunci: faktor-faktor dominan pemilihan perguruan tinggi, evaluasi kebijakan, deskripsi kuantitatif, analytical hierarchy process.

\begin{abstract}
The purpose of this study is to determine the dominant factors that influence in choosing a higher education institution for high school and vocational school students in the Bali province. This research is a policy evaluation research with exploratory research design. Data analysis method in this research is quantitative description. The sampling technique used is multistage random sampling. The sample in this research is the students of class XII SMA/SMK in Bali province which has 2.543 students from the total population of 128 schools. Data analysis technique used is AHP (Analytical Hierarchy Process). Based on 11 factors studied, it was found that the top 3 ranking related to the most dominant factor in determining the higher education in Bali province that is a motivation to work with eigenvector value $=0,3617$, educational cost with eigenvector value $=0,2030$, and higher education's product with eigenvector value $=0,0884$. Even if a separate analysis was conducted between high school and vocational school groups, there were similarities between the top three factors that
\end{abstract}


influenced the selection of higher education institutions such as motivation to work, education cost, and product. The results showed that there was no difference between high school and vocational groups on the most dominant factor in the selection of higher education institution, both high school and vocational groups chose the motivation to work is the most dominant factor. This shows that both high school and vocational high school students prioritize for working after graduating from university. Therefore, in the future the higher education institution should further promote the profile of its graduates compared to the university profile.

Keywords : the dominant factors of higher education selection, policy evaluation, quantitative description, analytical hierarchy process.

\section{PENDAHULUAN}

Pendidikan merupakan salah satu prioritas terpenting bagi sebagian besar masyarakat. Sebagian dari masyarakat memiliki harapan untuk dapat melanjutkan dan menyelesaikan pendidikannya hingga ke jenjang paling tinggi. Pendidikan mempunyai peranan yang sangat sentral dan strategis, terutama jika dikaitkan dengan upaya peningkatan mutu sumber daya manusia (SDM). Karena hanya dengan sumber daya manusia yang berkualitas akan tercipta peningkatan harkat dan martabat manusia yang sejati. Indriyati (2013) menyatakan bahwa kualitas sumber daya manusia dipandang sebagai salah satu faktor kunci dalam era perdagangan bebas.

Semakin tinggi persaingan dan tuntutan di dunia kerja juga membutuhkan sumber daya manusia yang berkualitas dengan segala kompetensi yang dimiliki, mampu mengembangkan diri serta bersama-sama membangun bangsa. Hal tersebut sesuai dengan amanat yang tercantum dalam Undang-Undang Sisdiknas no 22 tahun 2003 pasal 1 ayat 1 tentang pendidikan yang menyatakan bahwa "Pendidikan adalah usaha sadar dan terencana untuk mewujudkan suasana belajar dan proses pembelajaran agar peserta didik secara aktif mengembangkan potensi dirinya untuk memiliki kekuatan spiritual keagamaan, pengenalan diri, kepribadian, kecerdasan, akhlak mulia, serta keterampilan yang diperlukan dirinya, masyarakat, bangsa, dan negara.

Adapun salah satu tujuan dari masyarakat dalam meningkatkan mutu pendidikan yang lebih tinggi yang fokus pada satu bidang konsentrasi yang dibutuhkan untuk memasuki dunia kerja dengan memasuki lembaga perguruan tinggi. Perguruan tinggi mempunyai tanggungjawab dan peran yang sangat strategis untuk mengambil bagian dalam mengatasi permasalahan kualitas sumber daya manusia. Dari sebagian masyarakat yang memilih untuk melanjutkan dan menyelesaikan pendidikannya hingga ke jenjang yang lebih tinggi, maka mereka akan dihadapkan pada berbagai macam pilihan dan permasalahan dalam menentukan dan melanjutkan ke perguruan tinggi.

Lulusan siswa SMA/SMK dapat melanjutkan studinya ke jenjang pendidikan yang lebih tinggi, baik pada Perguruan Tinggi Negeri (PTN) maupun pada Perguruan Tinggi Swasta (PTS). Melanjutkan studi ke PTN maupun PTS merupakan pilihan masing-masing individu. Menentukan suatu pilihan harus cermat, yaitu terutama dalam memilih perguruan tinggi, harus mencari institusi pendidikan yang mampu memberikan pelayanan jasa pendidikan yang benarbenar mampu menghasilkan lulusan yang kompeten.

Selepas lulus SMA/SMK, siswa akan dihadapkan berbagai macam pertimbangan yakni melanjutkan pendidikan di perguruan tinggi atau langsung bekerja. Pengambilan keputusan siswa SMA/SMK untuk melanjutkan studi ke perguruan tinggi yang diinginkan merupakan suatu keputusan dimana siswa melakukan pertimbangan-pertimbangan yang disesuaikan dengan keadaan atau kondisi yang ada. Jika keadaan atau kondisi yang terlihat tidak sesuai dengan apa yang diharapkannya, maka akan terjadi keraguan yang dapat berakibat 
pada keputusan untuk tidak melanjutkan studi di tempat yang diharapkan (Putri, 2013). Di lain pihak, bagi lulusan sekolah menengah sendiri, studi ke jenjang perguruan tinggi dianggap sebagai salah satu cara untuk mewujudkan cita-cita mereka dan untuk berprestasi. Mereka juga menyadari pentingnya kuliah dengan benar dan selesai tepat waktu karena merupakan jaminan dan menjadi dasar bagi kesuksesan mereka di masa depan (Wibowo, 2012). Meningkatnya keinginan masyarakat untuk memiliki karier yang baik dan ketatnya persaingan, mendorong meningkatnya jumlah perguruan tinggi negeri maupun swasta yang tersebar di seluruh Indonesia.

Dewasa ini persaingan antar perguruan tinggi dalam merekrut mahasiswa baru semakin ketat. Masingmasing perguruan tinggi gencar melakukan berbagai program promosi. Semua upaya ini dilakukan oleh perguruan tinggi untuk merekrut mahasiswa baru yang bermutu tinggi. Mutu mahasiswa baru semakin banyak menjadi perhatian pengelola perguruan tinggi karena berperan penting dalam menunjang terciptanya proses pembelajaran yang berkualitas. Ke depan, selain aspek jumlah mahasiswa (kuantitas), aspek mutu mahasiswa (kualitas) juga menjadi salah satu tolak ukur dan pertimbangan penting keberhasilan pengelolaan sebuah perguruan tinggi (Wibowo, 2013).

Bersamaan dengan adanya penerimaan mahasiswa baru maka serangkaian strategi promosi dilakukan oleh para pengelola lembaga perguruan tinggi baik itu di media cetak, elektronik, iklan-iklan dan brosur-brosur yang disebar ke sekolah-sekolah baik SMA/SMK. Ramalu et.al (2013) menyatakan "Marketing and the promotion of an institution also plays a key role in the selection made by a prospective student" pernyataan ini mengisyaratkan bahwa pemasaran dan promosi sebuah institusi juga memainkan peran kunci dalam seleksi yang dilakukan oleh calon siswa, semakin bagus promosi yang dilakukan pihak pengelola perguruan tinggi maka peminat calon mahasiswa semakin banyak. Namun disisi lain, para pihak pengelola perguruan tinggi mengalami kesulitan dan belum efektif dalam mempromosikan perguruan tinggi, hal ini dikarenakan pihak pengelola perguruan tinggi tidak mengetahui faktor-faktor apa saja yang menentukan minat siswa SMA/SMK dalam memilih perguruan tinggi.Keputusan memilih suatu perguruan tinggi merupakan suatu keputusan investasi. Investasi tersebut harus menguntungkan konsumen setelah dinyatakan tamat dari perguruan tinggi.

Menurut Slameto (2010:180) mengemukakan, bahwa "Minat adalah suatu rasa lebih suka dan rasa keterikatan pada suatu hal atau aktivitas, tanpa ada yang menyuruh." Minat pada dasarnya adalah penerimaan akan suatu hubungan antara diri sendiri dengan sesuatu di luar diri. Semakin kuat atau dekat hubungan tersebut, semakin besar minat yang muncul. Minat dapat dipengaruhi oleh berbagai faktor baik yang berasal dari dalam diri maupun dari luar diri. Semakin pesatnya pertumbuhan perguruan tinggi membuat para calon mahasiswa memiliki banyak alternatif dan berbagai pertimbangan dalam memilih sebuah perguruan tinggi. Proses pengambilan keputusan dalam memilih perguruan tinggi tertentu sangat penting untuk diketahui oleh para pengelola perguruan tinggi melalui kajian perilaku calon mahasiswa.

Pertimbangan siswa dalam memilih perguruan tinggi berbeda satu sama lain. Hal ini disebabkan karena mereka memiliki bakat, minat, cita-cita dan persepsi atau pandangan yang berbeda dalam menilai peerguruan tinggi. Berdasarkan paparan diatas maka dapat diidentifikasi beberapa permasalahan dalam penelitian ini, yaitu : (1) Lulusan siswa SMA/SMK dalam memilih perguruan tinggi masih memiliki berbagai macam pertimbangan; (2) Strategi promosi perguruan tinggi ke masyarakat masih belum optimal dilakukan oleh pihak pengelola perguruan tinggi; (3) Pihak pengelola perguruan tinggi mengalami kesulitan dalam mempromosikan perguruan tinggi. dari latar belakang dan identifikasi permasalahan di atas, maka dapat dirumuskan permasalahan yang akan diteliti yaitu (1) Faktor-faktor apa saja 
yang berpengaruh dalam menentukan pemilihan perguruan tinggi dan (2) Bagaimana tingkat kepentingan masingmasing faktor yang berpengaruh dalam pemilihan perguruan tinggi baik kelompok SMA maupun kelompok SMK di provinsi Bali.

Identifikasi faktor-Faktor yang dominan mempengaruhi pemilihan perguruan tinggi dilakukan melalui kajian litelatur dan survey pendahuluan. Melalui kajian litelatur diperoleh 10 faktor antara lain : (1) biaya pendidikan, menurut Supriadi (2006) bahwa biaya (cost) dalam pengertian ini memiliki cakupan yang luas yakni semua jenis pengeluaran yang berkenaan dengan penyelenggaraan pendidikan, baik dalam bentuk uang maupun barang dan tenaga (yang dapat dihargakan dengan uang); (2) motivasi untuk bekerja, menurut Kartono (1991:82) motif seseorang untuk bekerja yaitu keharusan ekonomi; keinginn membina karir dan kesadaran bahwa pembangunan memerlukan tenaga kerja; (3) motivasi untuk beprestasi, menurut Lindgren (1976: 67) mengemukakan bahwa motivasi berprestasi sebagai suatu dorongan yang ada pada seseorang sehubungan dengan prestasi, yaitu menguasai, memanipulasi serta mengatur lingungan sosial maupun fisik, mengatasi segala rintangan dan memelihara kualitas kerja yang tinggi, bersaing melalui usahausaha untuk melebihi hasil kerja yang lampau, serta mengungguli hasil kerja yang lain; (4) lingkungan sosial, Dalyono (2010) mengatakan pengaruh langsung dari lingkungan sosial seperti dalam pergaulan sehari-hari, seperti keluarga, teman-teman, kawan sekolah dan lingkungan kerjanya dan sebagainya; (5) promosi, menurut Lupiyoadi (2006:120) promosi merupakan salah satu variabel dalam bauran pemasaran yang sangat penting dilaksanakan oleh perusahaan dalam memasarkan produk jasa; (6) citra perguruan tinggi, menurut Kotler (2005), citra sebuah organisasi merepresentasikan nilai-nilai seseorang dan kelompok-kelompok masyarakat yang mempunyai hubungan dengan organisasi tersebut; (7) produk, menurut
Kotler (2010:248) produk adalah segala sesuatu yang dapat memenuhi atau memuaskan kebutuhan dan keinginan manusia baik yang berwujud ataupun yang tidak berwujud; (8) proses, Ahyari (1994: 12) mengemukakan bahwa Proses dapat diartikan sebagai cara, metode maupun teknik untuk penyelenggaraan atau pelaksanaan dari suatu hal tertentu; (9) fasilitas pendidikan, menurut Arikunto (1988:103) menyatakan bahwa sarana pendidikan adalah semua fasilitas yang diperlukan dalam proses belajar mengajar baik bergerak maupun tidak bergerak agar pencapaian tujuan dapat berjalan lancar dan teratur, efektif dan efisien; (10) lokasi pendidikan, menurut Lupiyoadi (2011:92), lokasi adalah keputusan yang dibuat perusahaan atau instansi pendidikan berkaitan dengan di mana operasi dan stafnya akan ditempatkan.

Dalam mengambil suatu keputusan melanjutkan pendidikan ke jenjang yang lebih tinggi banyak hal yang perlu dipertimbangkan oleh siswa SMA/SMK. Terdapat beberapa faktor yang menjadi pertimbangan siswa dalam memilih suatu perguruan tinggi baik secara internal maupun eksternal sehingga siswa memutuskan memilih perguruan tinggi tersebut untuk melanjutkan pendidikan. Begitu pula bagi pengelola perguruan tinggi terdapat beberapa faktor yang menjadi pertimbangan dalam pengelolaan perguruan tinggi.Dari ke- 10 faktor di atas dikomfirmasi kembali melalui survey pendahuluan terdapat 1 faktor tambahan yaitu persepsi terhadap alumni, menurut Bimo (2004:70) mengungkapkan bahwa persepsi merupakan suatu proses pengorganisasian, penginterpretasian terhadap stimulus yang diterima oleh organisme atau individu sehingga menjadi sesuatu yang berarti, dan merupakan aktivitas yang integrated dalam diri individu.

Metode Anlytical Hierarchy Process (AHP) yang digunakan dalam menganalisis data dalam penelitian ini banyak digunakan pada penelitian sosial dan pendidikan seperti penentuan pemilihan mode transportasi; penentuan pemberian beasiswa; penentuan 
pertukaran pelajar dan lain-lain. AHP merupakan suatu model pendukung keputusan yang dikembangkan oleh Thomas L. Saaty. Model pendukung keputusan ini akan menguraikan masalah multi faktor atau multi kriteria yang kompleks menjadi suatu hirarki, menurut Saaty (1993), hirarki didefinisikan sebagai suatu representasi dari sebuah permasalahan yang kompleks dalam suatu struktur multi level dimana level pertama adalah tujuan, yang diikuti level faktor, kriteria, sub kriteria, dan seterusnya ke bawah hingga level terakhir dari alternatif. Beberapa penelitian yang menggunakan metode AHP dapat dijabarkan berikut ini. Hasil penelitian Khuntari (2015) untuk menentukan rekomendasi pemilihan jurusan perguruan tinggi dengan menggunakan Anlytical Hierarchy Process (AHP) menunjukkan bahwa rekomendasi untuk memilih jurusan berdasarkan dari kemampuan siswa, minat siswa dan kesukaan siswa. Penelitian Sahputra (2017) tentang keputusan pemilihan program studi di perguruan tinggi menunjukkan bahwa kriteria yang dipertimbangkan dalam memilih program studi yaitu biaya kuliah; akreditasi; fasilitas; dan beasiswa.

\section{METODE}

Penelitian ini dilaksanakan pada 35 SMA/SMK negeri dari 128 sekolah di provinsi Bali. Penelitian ini dilaksanakan melalui rancangan penelitian eksploratoris yang merupakan salah satu pendekatan penelitian evaluasi kebijakan. Teknik pengambilan sampel yang digunakan adalah Multi stage random sampling. Sampel dalam penelitian ini adalah siswa/siswi SMA/SMK negeri di provinsi Bali dengan jumlah responden 2.543 dari 35 SMA/SMK negeri di provinsi Bali.

Metode pengumpulan data yang digunakan dalam penelitian ini yaitu metode kuesioner. Kuesioner ini ditujukan kepada Siswa/siswi tempat responden bersekolah. Kuesioner dalam penelitian ini terdiri dari 11 faktor-faktor yang mempengaruhi dalam pemilihan perguruan tinggi dengan memberikan ranking pada setiap faktor.
Metode analisis data dalam penelitian ini adalah metode deskripsi dengan pendekatan kuantitatif. Teknik analisis data yang digunakan adalah analisis AHP (Analytical Hieararcy Process). Adapun tahapan metode AHP seperti pada gambar 1 di bawah ini.

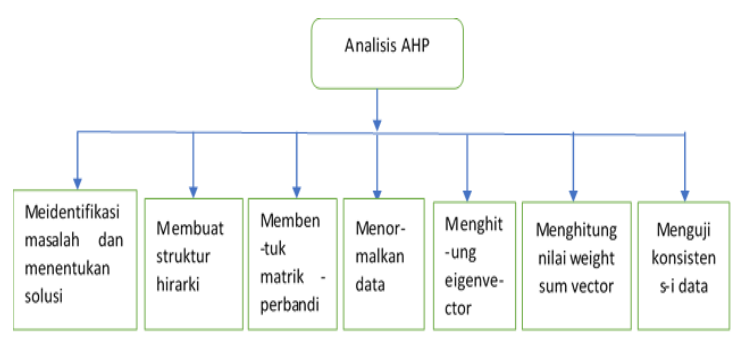

Gambar 1

Tahapan AHP

\section{HASIL DAN PEMBAHASAN}

Penelitian ini merupakan deskripsi kuantitatif untuk menentukan faktor-faktor dominan yang digunakan dalam pemilihan perguruan tinggi. Jumlah sekolah yang digunakan dalam penelitian ini terdiri dari 20 SMA dan 15 SMK. Keseluruhan sampel yang digunakan dalam penelitian ini adalah 2.543 siswa, yang terdiri dari 1.444 siswa SMA dan 1.099 siswa SMK yang mencakup kabupaten Buleleng, Badung, Gianyar, Klungkung, Bangli, Karangasem, Jembrana, Tabanan, dan Kota Denpasar. Adapun faktor-faktor yang menjadi daya tarik calon mahasiswa untuk memilih melanjutkan studi ke perguruan tinggi, berdasarkan dari hasil analisis AHP yang dilakukan pada kelompok SMA/SMK di provinsi Bali diperoleh bahwa dari sebelas faktor yang diteliti menunjukkan faktor yang paling dominan dalam menentukan siswa/siswi memilih melanjutkan studi ke perguruan tinggi adalah faktor motivasi untuk bekerja dengan nilai eigenvector $=0,3617$ seperti yang ditunjukkan pada tabel 1 di bawah ini.

Tabel 1

Hasil perhitungan Eigenvektor SMA/SMK Di Provinsi Bali

\begin{tabular}{|c|c|c|}
\hline Faktor & Jumlah & $\begin{array}{c}\text { Eigen- } \\
\text { vector }\end{array}$ \\
\hline Motivasi Untuk & 3,98 & 0,3617 \\
\hline
\end{tabular}




\begin{tabular}{|l|c|c|}
\hline \multicolumn{1}{|c|}{ Faktor } & Jumlah & $\begin{array}{c}\text { Eigen- } \\
\text { vector }\end{array}$ \\
\hline Bekerja & & \\
\hline Biaya Pendidikan & 2,23 & 0,2030 \\
\hline Produk & 0,97 & 0,0884 \\
\hline $\begin{array}{l}\text { Citra Perguruan } \\
\text { Tinggi }\end{array}$ & 0,80 & 0,0731 \\
\hline $\begin{array}{l}\text { Motivasi Untuk } \\
\text { Berprestasi }\end{array}$ & 0,60 & 0,0545 \\
\hline Proses & 0,52 & 0,0471 \\
\hline Lingkungan Sosial & 0,46 & 0,0418 \\
\hline Fasilitas Pendidikan & 0,39 & 0,0357 \\
\hline Lokasi Pendidikan & 0,34 & 0,0312 \\
\hline $\begin{array}{l}\text { Persepsi Terhadap } \\
\text { Alumni }\end{array}$ & 0,30 & 0,0270 \\
\hline Promosi & 0,25 & 0,0229 \\
\hline
\end{tabular}

Dengan demikian, faktor motivasi untuk bekerja adalah faktor yang paling dominan berpengaruh terhadap siswa/siswi SMA/SMK di Bali dalam memilih perguruan tinggi dibandingkan dengan faktor-faktor lainnya. Menurut Uno (2013:10), motivasi memasuki dunia kerja timbul karena adanya keinginan untuk melakukan kegiatan, adanya dorongan atau kebutuhan untuk melakukan kegiatan, adanya harapan dan cita-cita, adanya penghormatan atas diri, adanya lingkungan yang baik dan adanya kegiatan yang menarik. Mengacu pada teori diatas bahwa siswa/siswi SMA/SMK mempunyai keinginan untuk mencapai harapan dan cita-cita yaitu setelah lulus dari pergurua tinggi mereka mendapatkan pekerjaan sesuai dengan keinginan mereka dan sesuai dengan kompetensi yang dimiliki. Selain itu sesuai dengan teori Kartono (1991:82) bahwa motif seseorang untuk bekerja karena adanya keharusan ekonomi yaitu untuk memenuhi kebutuhan hidup.

Temuan ini memberikan makna, bahwa perguruan tinggi seharusnya dapat memberikan informasi selengkaplengkapnya terkait dengan bagaimana keterserapan lulusannya di lapangan kerja. Informasi ini akan dapat mendorong minat masyarakat untuk memilih perguruan tinggi tersebut. Temuan penelitian ini sejalan dengan hasil penelitian yang dilakukan oleh Suryani (2010) yang menyatakan bahwa faktor motivasi mempengaruhi dalam pengambilan keputusan memilih fakultas ekonomi di Universitas Islam Sumatera Utara Al Munawaroh Medan.

Tingkat kepentingan masing-masing faktor yang berpengaruh dalam menentukan pemilihan perguruan tinggi, khusus untuk kelompok SMA di provinsi Bali, juga diperoleh bahwa faktor motivasi untuk bekerja merupakan faktor dominan yang paling berpengaruh terhadap perilaku calon mahasiswa memilih perguruan tinggi. Hal ini disebabkan karena adanya dorongan dalam diri untuk mencapai tujuan mendapatkan pekerjaan di masa yang akan datang setelah mereka lulus dari perguruan tinggi. Berbeda dengan faktor motivasi untuk bekerja, hasil analisis data yang diperoleh dari kelompok SMA menunjukkan bahwa faktor persepsi terhadap alumni merupakan faktor yang paling tidak dominan dengan nilai eigenvector = 0,0227 .

Menurut Kotler (2009:204), seseorang bisa memiliki persepsi yang berbeda terhadap benda yang sama, dalam hal ini persepsi siswa/siswi dalam memilih perguruan tinggi memiliki pandangan yang berbeda mengenai alumni dari lulusan perguruan tinggi tersebut dikarenakan kebanyakan mereka tidak bisa mengingat informasi yang diberikan kepada mereka, tetapi masih bisa mempertahankan informasi yang mendukung sikap dan keyakinan mereka. Hasil temuan pada kelompok SMA di provinsi Bali menunjukkan hasil temuan yang sama dengan kelompok SMA di per masing-masing kabupaten di provinsi Bali. Hasil temuan pada kelompok SMA di provinsi Bali menunjukkan hasil temuan yang sama dengan kelompok SMA di per masing-masing kabupaten di provinsi Bali.

Berdasarkan hasil temuan dari sembilan kabupaten di provinsi Bali, enam kabupaten pada kelompok SMA memilih faktor motivasi untuk bekerja sebagai faktor yang paling dominan (ranking 1) (kabupaten Buleleng; kabupaten Kelungkung; kabupaten Badung; kabupaten Gianyar; kabupaten Jembrana; kabupaten Tabanan). Hal ini dianalogikan 
dengan teori dari Kartono (1991:82) bahwa minat siswa/siswi masuk ke perguruan tinggi adanya keinginan untuk membina karir, hal ini terjadi pada kondisi seseorang yang meskipun ekonominya tidak memerlukan, namun tetap bekerja demi karir dan ada juga yang bermotifkan ingin menggunakan keahlian yang dimilikinya.

Selain faktor motivasi untuk bekerja, 2 faktor teratas lainnya pada kelompok SMA di provinsi Bali adalah faktor biaya pendidikan dan faktor produk. Faktor biaya pendidikan sebagai pertimbangan kedua setelah motivasi untuk bekerja. Menurut Gaffar (1991) bahwa biaya langsung menyentuh aspek dan proses pendidikan yang dikeluarkan untuk keperluan pelaksanaan pengajaran dan kegiatan belajar, hal ini menunjukkan bahwa faktor biaya pendidikan merupakan salah satu pertimbangan lulusan SMA di provinsi Bali untuk melanjutkan ke perguruan tinggi.

Sedangkan faktor ketiga teratas pada kelompok SMA yaitu faktor produk. Faktor produk yang dimaksud dalam penelitian ini adalah berbagai hal yang ditawarkan perguruan tinggi kepada stakeholder-nya, seperti: program studi, kurikulum, layanan akademik maupun nonakademik, dan lainnya. Hal ini beranalogi dari teori Kotler (2010:248) yang menyatakan bahwa produk adalah segala sesuatu yang dapat memenuhi atau memuaskan kebutuhan dan keinginan manusia baik yang berwujud ataupun yang tidak berwujud. Bagi calon mahasiswa pastinya akan memikirkan program studi yang mereka pilih agar sesuai dengan potensi yang mereka miliki.

Selanjutnya, faktor lainnya yang berpengaruh dalam memilih perguruan tinggi pada kelompok SMA di provinsi Bali yaitu faktor citra perguruan tinggi (ranking 4). Faktor ini lebih penting dibandingkan dengan faktor motivasi untuk berprestasi (ranking 5). Hal ini menjukkan bahwa citra/image perguruan tinggi yang baik akan memberikan citra/image yang baik pula terhadap mahasiswa. Citra/image perguruan tinggi yang baik, akan menghasilkan lulusan yang baik dan berkualitas.

Faktor proses yang berada pada ranking 6 , lebih berpengaruh dibandingkan dengan faktor lingkungan sosial (ranking 7). Hasil penelitian ini menunjukkan bahwa calon mahasiswa lebih mementingkan proses belajar mengajar yang dilakukan oleh perguruan tinggi, dibandingkan dengan pengaruh dari keluarga, teman maupun masyarakat dalam memilih perguruan tinggi. Faktor berikutnya adalah fasilitas pendidikan (ranking 8) lebih penting dibandingkan dengan faktor lokasi pendidikan (ranking 9). Hal ini menunjukkan bahwa sarana prasarana menjadi perhatian bagi calon mahasiswa dibandingkan dengan lokasi dari perguruan tinggi itu sendiri.

Faktor promosi merupakan faktor yang menempati ranking 10, dibandingkan dengan faktor persepsi terhadap alumni yang berada pada ranking 11 . Hal ini menunjukkan bahwa pemasaran atau promosi dari pihak perguruan tinggi mempengaruhi sikap dan perilaku calon mahasiswa dalam memilih perguruan tinggi untuk melanjutkan studi mereka dibandingkan faktor persepsi tentang lulusan. Penelitian ini mengidentifikasi bahwa perspesi tentang lulusan tidak menjadi perhatian lebih penting dibandingkan dengan promosi yang dilakukan selama ini oleh perguruan tinggi. Hasil temuan berdasarkan analisis AHP pada kelompok SMK di provinsi Bali menunjukkan bahwa faktor motivasi untuk bekerja dengan nilai eigenvector $=0,3604$ merupakan faktor paling dominan (ranking 1) dibandingkan dengan 10 faktor lainnya dalam pemilihan perguruan tinggi. Hal ini sejalan dengan hasil analisis data pada kelompok SMA/SMK dan kelompok SMA secara terpisah. Melihat hal tersebut bahwa siswa/siswi menengah kejuruan dengan keahlian dan potensi yang mereka miliki ketika lulus ingin mengembangkan keahliannya di jenjang pendidikan yang lebih tinggi agar nantinya dapat membina karir dengan baik. Sejalan dengan teori Kartono (1991:82) bahwa ada motif seseorang untuk bekerja dengan berkeinginan untuk membina karir. 
Faktor berikutnya yang dominan dalam pemilihan perguruan tinggi adalah biaya pendidikan dengan nilai eigenvector $=0,2231$ (ranking 2) dan faktor produk dengan eigenvector $=0,0833$ (ranking 3 ). Adapun beberapa faktor lainnya yang mengikuti adalah faktor motivasi untuk berprestasi (ranking 4) dan faktor citra perguruan tinggi (rangking 5). Hasil ini berbeda dengan temuan pada kelompok SMA, dimana hasil analisis dengan metode AHP pada kelompok SMK lebih mementingkan faktor motivasi berprestasi dibandingkan dengan faktor citra/image perguruan tinggi. Saat ini citra/image perguruan tinggi seringkali diciptakan atau dimanipulasi oleh perguruan tinggi hanya semata-mata meraup peminat calon mahasiswa. Kadangkala pencitraan ini tidak sesuai dengan kenyataan yang ada.

Selanjutnya faktor proses (ranking 6) lebih penting dibandingkan dengan faktor lokasi pendidikan (ranking 7), artinya bahwa calon mahasiswa lebih mementingkan proses belajar mengajar dibandingkan dengan lokasi universitas itu sendiri. Dewasa ini, tidak lagi calon mahasiswa mengejar universitasuniversitas yang berada di kota besar. Namun dimana pun universitas itu, asal memberikan proses pembelajaran yang berkualitas, maka dapat menarik minat calon mahasiswa untuk memilih universitas tersebut.

Hasil penelitian ini juga menunjukkan bahwa pengaruh lingkungan sosial (ranking 8) seperti (teman, keluarga, dan masyarakat secara luas) tidak lagi menjadi faktor dominan dalam menentukan perguruan tinggi. Calon mahasiswa dapat menentukan pilihan perguruan tingginya dengan beberapa indikator sebagai pertimbangan dengan urutan sesuai dengan prioritasnya, yaitu: (1) motivasi untuk bekerja, (2) biaya pendidikan, (3) produk yang ditawarkan, (4) motivasi untuk berprestasi, (5) citra perguruan tinggi, (6) proses belajar mengajar, dan (7) lokasi pendidikan.

Selanjutnya hasil penelitian menunjukkan bahwa persepsi terhadap alumni (ranking 9) lebih penting dibandingkan dengan fasilitas pendidikan (ranking 10), hal ini menunjukkan bahwa siswa/siswi lebih melihat keterserapan lulusan setelah lulus dibandingkan saranaprasarana yang disedikan di perguruan tinggi.

Pada kelompok SMK memilih faktor promosi (rangking 11) sebagai faktor yang paling tidak dominan. Melihat hal tersebut, menunjukkan bahwa kesan atau pandangan terhadap lulusan perguruan tinggi tidak begitu penting bagi siswa/siswi SMA, sedangkan pada kelompok SMK menyatakan bahwa informasi atau sosialisasi seperti: iklan, informasi di media cetak maupun dijital, dan promosi lainnya tidak mempengaruhi minat calon mahasiswa untuk melanjutkan studinya ke perguruan tinggi tertentu.

Namun jika dilihat di masingmasing kabupaten untuk kelompok SMK, menunjukkan bahwa terjadi perbedaan pada faktor yang paling dominan. Di kabupaten Karangasem, faktor yang paling dominan adalah biaya pendidikan dengan nilai eigenvector $=0,3909$. Faktor biaya menjadi pertimbangan paling penting bagi calon mahasiswa SMK di Karangasem untuk memilih perguruan tinggi. Hal ini sangat wajar, karena kabupaten Karangasem adalah kabupaten yang memiliki rata-rata pendapatan perkapita masyarakat yang tergolong rendah.

Berbeda dengan kabupaten Karangasem, di kabupaten Tabanan siswa/siswi SMK menempatkan faktor lokasi pendidikan sebagai faktor yang paling dominan dengan nilai eigenvector $=$ 0,2635 . Sedangkan di kota Denpasar, siswa/siswi SMK lebih mementingkan faktor produk (eigenvector $=0,3410$ ) dibandingkan faktor-faktor lainnya. Bagi calon mahasiswa dari kelompok SMK di kabupaten Badung dan kota Denpasar, produk yang ditawarkan pihak perguruan tinggi menjadi perhatian yang sangat penting bagi calon mahasiswa, mengingat SMK merupakan sekolah kejuruan yang telah memberikan keahlian dan pengetahuan yang sangat spesifik. Sehingga hal ini yang menjadi pendorong bagi calon mahasiswa dari SMK untuk memilih perguruan tinggi yang memiliki program studi yang sesuai dengan bidang keahliannya di sekolah menengah 
kejuruan. Dengan berbedanya faktor paling dominan di masing-masing kabupaten, baik kelompok SMA dan SMK, maka hal ini dapat dijadikan acuan bagi perguruan tinggi khususnya di Bali dalam menentukan target dan konten yang harus dipromosikan kepada masyarakat.

Hasil temuan secara keseluruhan menunjukkan bahwa faktor yang paling dominan bagi siswa/siswi SMA/SMK di provinsi Bali dalam memilih perguruan tinggi adalah faktor motivasi untuk bekerja dengan nilai eigenvector $=0,3617$. Hal ini menujukkan bahwa motivasi calon mahasiswa untuk melanjutkan ke perguruan tinggi adalah untuk memperoleh pekerjaan yang layak setelah mereka lulus, sehingga dapat mencapai kehidupan yang lebih baik. Temuan ini memberikan indikasi bahwa perguruan tinggi perlu tetap mencermati kebutuhan calon mahasiswa akan ilmu pengetahuan dan teknologi, keinginan dan harapan yang ingin dicapai mahasiswa dimasa akan datang. Untuk dapat memenuhi keinginan dan harapan tersebut maka mutu lulusan harus berkualitas dan sesuai dengan kebutuhan dunia kerja di masa datang. Sehingga calon mahasiswa memiliki keyakinan terhadap lembaga pendidikan atau program studi yang dipilih, yang pada akhirnya akan membentuk persepsi mahasiswa tentang kualitas lembaga pendidikan tinggi dan alumni di perguruan tinggi tersebut. Hasil temuan ini sejalan dengan Wibowo (2013) yang menunjukkan bahwa faktor motivasi untuk bekerja dalam penentu intensi studi ke perguruan tinggi.

Berdasarkan hasil temuan penelitian dari keseluruhan SMA/SMK di provinsi Bali selain faktor motivasi untuk bekerja sebagai faktor dominan, calon mahasiswa memiliki pertimbangan yang lain dalam menentukan perguruan tinggi, yaitu faktor biaya pendidikan berada pada peringkat kedua. Hal ini menunjukkan bahwa selain mempertimbangkan agar nantinya terserap di lapangan kerja, biaya pendidikan menjadi pertimbangan kedua setelah motivasi untuk bekerja. Menurut Dedi Supriadi (2007) biaya pendidikan merupakan salah satu komponen instrumental yang sangat penting dalam penyelenggaraan pendidikan. Jadi besarnya biaya yang dibayarkan terhadap universitas memang menjadi penentu bagi calon mahasiswa untuk menentukan pilihan (Wulandani, 2017).

Faktor ketiga adalah produk. Produk yang dimaksud dalam penelitian ini adalah hal-hal yang ditawarkan oleh masing-masing perguruan tinggi dalam proses belajar mengajar. Karena dalam sebuah perguruan tinggi produk yang baik dan diikuti oleh proses yang berkualitas akan menghasilkan lulusan yang berdaya saing. Sebelum memilih perguruan tinggi calon mahasiswa membutuhkan informasi mengenai status akreditasi, kurikulum, program studi yang akan dimasukinya, karena dengan melihat produk yang ada di univeritas tersebut akan menarik minat calon mahasiswa untuk studi ke perguruan tinggi sesuai dengan harapan mereka.

Namun terdapat temuan dalam penelitian ini yang bertolak belakang dengan apa yang sedang dilakukan perguruan tinggi dalam menarik minat calon mahasiswanya. Perguruan tinggi sedang berlomba-lomba melakukan promosi (rangking 11) terkait dengan informasi umum perguruan tingginya. Namun yang diharapkan oleh calon mahasiswa lebih pada profil lulusan, yaitu keterserapan lulusannya di lapangan kerja, kualitas lulusan, waktu tunggu lulusan dalam mendapatkan pekerjaan, serta penilaian penguna lulusan.

Secara umum, penelitian ini memberikan kontribusi yang sangat berharga terutama bagi pengelola perguruan tinggi. Temuan penelitian ini membantu pengelola perguruan tinggi dalam pengambilan keputusan/kebijakan untuk meningkatkan kualitas dan kuantitas mahasiswanya. Faktor motivasi untuk bekerja sebagai kontribusi utama dan terpenting dari penelitian ini harus selalu dicermati dan dievaluasi secara periodik, terutama dalam konteks persaingan dengan perguruan tinggi lainnya. Untuk memastikan implementasi faktor motivasi untuk bekerja sebagai penentu studi ke perguruan tinggi, pengelola perguruan tinggi lebih fokus pada upaya untuk menciptakan dan meningkatkan berbagai 
manfaat dan nilai bagi mahasiswa dan calon mahasiswa baru dari produk atau jasa yang ditawarkan. Selain itu pihak pengelola tinggi lebih fokus untuk memberikan informasi keterserapan lulusan di dunia kerja kepada calon mahasiswa. Dengan diketahuinya tingkat kepentingan faktor-faktor yang berpengaruh dalam menentukan pemilihan perguruan tinggi, maka perguruan tinggi bisa membenahi diri baik secara internal maupun eksternal.

Secara internal, bisa dilakukan perbaikan kualitas pembelajaran, biaya pendidikan dan fasilitas pendukung pembelajaran sehingga menghasilkan lulusan yang berdaya saing. Perbaikan secara eksternal melalui promosi perguruan tinggi dapat mengutamakan profil lulusannya seperti keterserapan lulusan di lapangan kerja, beberapa lama waktu lulusan untuk mendapatkan pekerjaaan atau bagaimana penilaian kualitas lulusan dari perguruan tinggi.

\section{SIMPULAN}

Berdasarkan analisis yang dilakukan adapun kesimpulan dalam penelitian ini sebagai berikut :

1. Berdasarkan hasil analisis yang dilakukan di SMA/SMK provinsi Bali menunjukkan bahwa faktor motivasi untuk bekerja merupakan faktor dominan (ranking 1) dengan nilai eigenvector $=0,3617$. Kemudian pada peringkat kedua faktor biaya pendidikan dengan nilai eigenvector $=0,2030$ dan pada peringkat ketiga faktor produk dengan nilai eigenvector $=$ 0,0884 .

2. Berdasarkan hasil analisis per kabupaten, terdapat perbedaan karakteristik calon mahasiswa pada beberapa kabupaten di provinsi Bali. Dari 9 kabupaten pada kelompok SMA di provinsi Bali, 6 kabupaten memilih faktor motivasi untuk bekerja sebagai faktor dominan, 2 kabupaten (Karangasem dan Bangli) menempatkan biaya pendidikan sebagai faktor dominan dan kota denpasar menempatkan faktor produk ebagai faktor dominan. Hasil analisis per kabupaten pada kelompok SMK di provinsi Bali, 6 kabupaten memilih faktor motivasi untuk bekerja sebagai faktor dominan, 3 kabupaten lainnya seperti (kabupaten Karangsem memilih faktor biaya pendidikan, kabupaten Tabanan memilih faktor lokasi pendidikan dan kota Denpasar memilih faktor Produk sebagai faktor dominan).

3. Faktor motivasi untuk bekerja, biaya pendidikan, dan produk yang ditawarkan perguruan tinggi merupakan faktor-faktor kritikal yang harus dipertimbangkan oleh perguruan tinggi untuk menarik minat calon mahasiswanya.

4. Faktor promosi merupakan faktor yang berada diprioritas paling rendah, karena calon mahasiswa tidak memerlukan lagi promosipromosi terkait dengan informasi umum perguruan tinggi. Namun informasi yang dibutuhkan oleh calon mahasiswa adalah informasi-informasi yang komprehensif terkait dengan (1) profil lulusan (seperti: keterserapan lulusan perguruan tinggi di lapangan kerja, waktu tunggu lulusan dalam mendapatkan pekerjaan, penilaian pengguna terhadap lulusan perguruan tinggi); (2) biaya pendidikan, serta (3) produk yang ditawarkan oleh perguruan tinggi (seperti: program studi, kurikulum, status akreditasi, dll.).

5. Biaya pendidikan yang pantas masih menjadi faktor kritikal yang dipertimbangkan oleh calon mahasiswa, khususnya bagi siswa/siswi SMA/SMK di provinsi Bali.

\section{SARAN}

Berdasarkan hasil dan keterbatasan penelitian yang dilakukan, berikut dapat 
dijabarkan beberapa saran baik, dari aspek teoritis maupun praktis.

1. Perguruan tinggi harus berupaya dalam memahami faktor-faktor yang mendukung sikap calon mahasiswa untuk memilih perguruan tinggi tertentu. Kebijakan berkaitan dengan perbaikan baik secara akademik maupun non-akademik internal perguruan tinggi dalam mengakomodir faktor-faktor yang dominan berpengaruh dalam pemilihan perguruan tinggi, seperti: motivasi untuk bekerja, biaya pendidikan, produk, proses, dan lain sebagainya, sehingga mendorong motivasi calon mahasiswa untuk masuk ke perguruan tinggi tersebut.

2. Pengelola perguruan tinggi harus lebih mengedepankan kualitas yang tinggi sebagai modal utama bagi luaran (alumni) untuk mendapatkan atau menciptakan pekerjaan, yang pada akhirnya akan menjadi salah satu rujukan bagi calon mahasiswa untuk memilih perguruan tinggi tersebut.

3. Untuk peneliti selanjutnya agar melakukan penelitian yang lebih mendalam pada sekolah SMA/SMK swasta mengenai faktor-faktor dominan yang berpengaruh terhadap pemilihan perguruan tinggi di provinsi Bali.

4. Untuk peneliti selanjutnya agar melakukan analisis AHP (Analytcal Hierarchy Process) sampai dengan pembuatan pengambilan keputusan dengan system.

\section{DAFTAR RUJUKAN}

Agus, AHyari. 1994. Penganggaran Perusahaan, Pendekatan Kuantitatif, Edisi 1. Yogyakarta : BPFE.

Bimo, Walgito, 2004. Pengantar Psikologi Umum.Jakarta: Andi.

Gaffar, M. Fakry. 1991.Konsep dan Filosofi Biaya Pendidikan. Mimbar Pendidikan.

Indriyanti,Dkk.2013."Faktor-Faktor Yang Memengaruhi Minat Melanjutkan
Pendidikan Ke Perguruan Tinggi Pada Siswa Kelas Xii Akuntansi Smk Negeri 6 Surakarta Tahun 2013". Jurnal, Jupe UNS, Vol. 1, No. 2, Hal $1 \mathrm{~s} / \mathrm{d}$ 10. Surakarta: Universitas Sebelas Maret.

Kartini, Kartono. (1990). Psikologi Perkembangan Anak :Bandung CV Manda.

Kotler, Philip. 2009. Manajemen Pemasaran. Jakarta : Erlangga.

Kotler,Philip. $2010 . \quad$ Manajemen Pemasaran,Edisi tiga belas Bahasa Indonesia. Jilid 1 dan 2. Jakarta: Erlangga.

Lupiyoadi dan Hamdani. 2011. Manajemen Pemasaran jasa. .Jakarta: Salemba Empat.

Putri, Karina.P. 2011." Analisis Pengaruh Brand Image, Biaya Pendidikan, Dan Fasilitas Pendidikan Terhadap Keputusan Mahasiswa Melanjutkan Studi Pada Program Diploma lii Fakultas Ekonomi Universitas Diponegoro Semarang". Skripsi. Semarang: Universitas Diponegoro.

Saaty, Thomas L. 1993. Pengambilan Keputusan Bagi Para Pemimpin, Proses Hirarki Analitik untuk Pengambilan Keputusandalam Situasi yang Kompleks. Setiono L, penerjemah; Peniwati K, editor. Jakarta: PT.Pustaka Binaman Pressindo. Terjemahan dari: Decision Making for Leaders The Analytical Hierarchy Process for Decisions in Complex World.

Supriadi, Dedi. 2006. Satuan Biaya Pendidikan Dasar dan Menengah, Bandung: Remaja Rosdakarya.

Slameto. 2010. Belajar dan Faktor-Faktor yang Mempengaruhinya. Jakarta: PT Rineka Cipta.

Suryani, W.2013."Faktor-faktor yang Mempengaruhi Mahasiswa Memilih Fakultas Ekonomi Iniversitas Islam Sumatera Utara AL Munawaroh Meda". Jurnal Modernisasi, Volome 9 Nomor 1. Sumatera Utara: Universitas Sumatera Utara.

Uno.B.Hamzah. 2011. Teori Motivasi dan Pengukurannya: Analisis di Bidang Pendidikan. Jakarta: Bumi aksara. 
Jurnal_ep, Vol. 8 No. 2, Agustus 2018

Wibowo, A.J.I. dan Hardianto, F.N. 2012, "Determinan Intensi Studi ke Jenjang Pendidikan Tinggi: Studi Eksploratif pada Siswa Sekolah Menengah Atas di Bandung". Jurnal. Bandung :Universitas Widyatama.

Wulandani,P dan Roni Saputra. 2017."Pengambilan Keputusan Mahasiswa Dalam Memilih Perguruan Tinggi Swasta Di Pekanbaru". Jurnal Sains Sosial dan Humaniora. Pekanbaru: Universitas Abdurrab Pekanbaru. 